\title{
Introduction
}

\section{Megaregionalism 2.0: Trade and Innovation in Global Networks - Towards an Enlightened Globalization Agenda}

\author{
Dieter Ernst \\ East-West Center and Centre for International \\ Governance (CIGI)
}

Michael G. Plummer

Johns Hopkins University, SAIS, and East-West Center

\section{Capturing gains from trade for innovation:}

Pathways to Megaregionalism 2.0?

In November 2016, the United States elected a president who, for the first time in the post-war era, promised to openly embrace protectionism to 
"make America great again". 1 This unabashed inward-looking approach of US trade diplomacy raises new challenges for the study of trade and innovation.

Prospects for gains from trade and investment liberalization are arguably greater than ever before, but realizing them has never been more complicated. The globalized economy requires not only lower border restrictions — such as tariffs and non-tariff barriers — but also behind-the-border policy harmonization and rules for the digital economy. "Megaregionalism" in the Asia-Pacific region has emerged as a promising potential vehicle for promoting innovation and productivity — both essential to raising living standards — via trade and investment links. Moreover, governments need to adopt a new set of well-funded social and other support policies (including innovation policies) to facilitate structural adjustment in efficient and equitable ways. We might call this two-dimensional set of policy challenges i.e., maximizing gains from globalization and effectively managing the process — "Megaregionalism 2.0".

This book, Megaregionalism 2.0: Trade and Innovation within Global Networks, presents new research insights for policy debates on how to strengthen the gains from trade for innovation through an inclusive trading environment that promotes productivity, while at the same time facilitating access to knowledge for all. The goal is to open up space for new agenda-setting research on this critically important policy challenge. This opening chapter introduces these issues by: (1) emphasizing the role that economic policy needs to play in ensuring that gains from trade for innovation are shared by all and that losses are minimized (Section 2); (2) evaluating the risks involved in the emerging "economic nationalism" that has been growing for some time but, with Brexit and the election of Donald Trump as US President, is now shaping policy (Section 3); (3) casting these issues in light of the new megaregionalism trend (Section 4); and (4) reviewing how the innovation and trade nexus (Section 5) might be affected by the alternative scenarios of megare-

\footnotetext{
${ }^{1}$ Tumulty, Karen, "How Donald Trump came up with 'Make America Great Again'”, Washington Post, January 18, 2017. To be sure, other administrations used various forms of protectionism to pursue political objectives; still, they never advocated it as a development strategy.
} 
gionalism in the future (Section 6). The final section reviews some of the salient messages from the book's 19 chapters that lay out key building blocks of Megaregionalism 2.0.

\section{Gains from trade for innovation - An evolving research agenda}

With the backlash against globalization, "protectionist bilateralism" describes the current direction of US trade diplomacy. For example, the US government has withdrawn from the Transpacific Partnership agreement (TPP), which was considered to be the gold standard of the new "megaregionalism" trend, vowing to only undertake bilateral, rather than regional, agreements. It is reopening NAFTA negotiations and has threatened to do the same with the Korea-US Free-trade Agreement (KORUS). It has promised an "America First" trade agenda that threatens countries experiencing bilateral trade surpluses with the United States with punitive tariffs. It has been especially critical of China, which it has accused of myriad unfair practices including dumping, currency manipulation, intellectual property theft, and discrimination against foreign investors.

It is thus time to highlight once again the critical role that international trade and investment partnerships can play in fostering sustainable growth and prosperity, decreasing poverty, reducing inequality, and lowering risks of international conflict. Economic policy is key in promoting international economic integration. Equally important however is the critical role that economic policy plays in ensuring that gains and losses from trade for innovation are shared by all. As digital technology and geopolitical shifts rapidly transform the global economy, all the more important are domestic support policies that seek to foster economic growth, competitiveness and prosperity through productivity-enhancing innovation. ${ }^{2}$ Greater attention to such

\footnotetext{
${ }^{2}$ For a theoretical foundation, see Chapter 12. For key contributions to the economics of innovation policy, see Perez, Carlota, 2002. Technological Revolutions and Financial Capital: The Dynamics of Bubbles and Golden Ages, Edward Elgar, Cheltenham, UK, 198 pages, and the contributions by Richard R. Nelson, David C. Mowery and Jan Fagerberg in Oxford Handbook of Innovation, 2002, edited by Jan Fagerberg, David C. Mowery, and Richard R. Nelson.
} 
domestic support policies underscores the essence of Megaregionalism 2.0. The relevance of the corresponding research agenda becomes clear when one considers the following long-term developments that are eroding the innovation capacity of the United States:

- The secular decline of public funding for basic and applied research needed to improve competitiveness and the creation of quality jobs;

- The long-term decline of corporate research in the United States, while other countries (especially China) are rapidly increasing their investment in R\&D and in the development of frontier technologies that are critical for, inter alia, economic growth, employment, and defense in the $21^{\text {st }}$ century ${ }^{3}$;

- The first budget proposal from the White House (May 2017) which recommends a drastic decline in funding for government agencies with responsibilities related to supporting investment, education, and knowledge diffusion for critical frontier technologies and for the provision of public goods related to the environment, health, economic development, and conflict resolution.

The distribution of gains from trade for innovation is of even greater concern for emerging and developing countries. While this is a highly divergent group, access to foreign technology (as manifested in licensing fees and conditions) is of critical importance for all of these countries. ${ }^{4}$ They lag well behind the United States and other advanced countries given their stage of development, human capital, and other resources and capabilities, and hence pursue quite different growth models and development strategies. Most importantly, barriers to innovation remain substantial in these countries, ranging from severe quality shortcomings in education to

\footnotetext{
${ }^{3}$ The drastic decline in corporate research is documented in a series of conferences, e.g., Conference on Innovation - The Decline in Corporate Research: Should We Worry? March 31, 2017, at Duke University's "Duke in DC" offices in Washington, DC.

${ }^{4}$ See Kim, Linsu and Richard R. Nelson, eds, 2000, Technology, Learning, and Innovation: Experiences of Newly Industrializing Economies; and Ernst, D., L. Mytelka and T. Ganiatsos (1998a), 'Learning, Technological Capability Building and Sustainable Export Growth', in D. Ernst, L. Mytelka and T. Ganiatsos, eds, Technological Capabilities and Export Success in Asia. London: Routledge.
} 
plagiarism in science, a weak and fragmented innovation system, and constraints to entrepreneurship and private R\&D investment. These differences in economic structure are acknowledged in the World Trade Organization (WTO)'s "special and differential treatment" provisions for trade agreements which, in principle, give developing countries special rights. ${ }^{5}$

Research on trade and innovation in the context of megaregional trade agreements cuts across many disciplinary boundaries. ${ }^{6}$ To address this challenge, this book brings together chapters from trade economists, policymakers, and trade negotiators, as well as from experts on innovation, intellectual property rights, competition law, technical standards, labor standards, and industrial development.

Gains from trade have been the subject of intense debate for centuries. Trade theory has focused on "the proposition that freedom of [international] trade is on the whole economically more beneficial than protection". 7 In the last half of the $20^{\text {th }}$ century, globalization culminated in the emergence of international corporate networks that integrate dispersed production, engineering, product development, and research across geographic borders. Knowledge-sharing is the glue that keeps these networks growing, strengthening the potentially powerful link between trade and innovation. ${ }^{8}$

New research has documented that international trade today is closely intertwined with foreign direct investment (FDI) as part of increasingly complex global value chains or global production networks (GPNs). ${ }^{9}$

\footnotetext{
${ }^{5}$ WTO. n.d.(a). Special and Differential Treatment Provisions. Trade and Development Committee. Available at www.wto.org/english/tratop_e/devel_e/dev_special_differential_ provisions_e.htm.

${ }^{6}$ See the important contribution by Feldman, M. and N. Lowe. (2017). "Evidence-Based Economic Development Policy." Innovations: Technology, Governance, Globalization, 11(3), 34-49.

${ }^{7}$ Johnson, H. (1977, p. 187), as quoted in Irwin, D. A. (1996). Against the Tide. An Intellectual History of Free Trade. Princeton University Press, Princeton, New Jersey: p. 3.

${ }^{8}$ See Chapter 4 (Beyond value capture - Exploring innovation gains from global networks) ${ }^{9}$ On the proliferation of these networks, see Ernst, D., 1997, From Partial to Systemic Globalization: International Production Networks in the Electronics Industry, Berkeley Roundtable on the International Economy (BRIE) Working Paper 98, April: 113 pages; Ernst, D. and P. Guerrieri (1998). "International Production Networks and Changing Trade
} 
Trade theory demonstrates how trade and global networks can increase global incomes substantially via efficiency-enhancing structural adjustment, economies of scale and scope via an international - rather than national - marketplace, improved incentives for investment in technology, and greater competition. There is broad consensus among trade and development economists that, in principle, a country's integration into global networks may facilitate access to best-practice technology and management approaches.

Integration into global networks could thus enable developing countries to overcome "barriers to exporting by accommodating specialization in narrow business functions and niche activities and [to] limit dependence on the degree of industrial development and broader skills set in the country" (OECD and World Bank, 2015). A new "gains from trade" doctrine for economic development has emerged that emphasizes the role of global network integration as "the $21^{\text {st }}$ century's fast lane to industrial development" (Baldwin, 2013, 2014). By joining GPNs, it is argued that "developing countries can benefit from foreignoriginated intellectual property, trademarks, managerial and business practices, marketing expertise, and organizational models" (Taglioni and Winkler, 2014).

This is in line with important insights from Paul Romer's "endogenous growth theory", which states that trade provides access to "new types of goods and new types of productive activities being introduced from abroad" and thus stimulates productivity and technology diffusion. ${ }^{10}$ To facilitate such global knowledge sourcing, countries have engaged in various rounds of trade liberalization and are searching for ways to

patterns in East Asia: The Case of the Electronics Industry". Oxford Development Studies, 26(2); Ernst, D. and L. Kim (2002). "Global Production Networks, Knowledge Diffusion and Local Capability Formation". Research Policy, special issue in honor of Richard Nelson and Sydney Winter; Ernst, D., "Complexity and Internationalization of Innovation: Why is Chip Design Moving to Asia?". International Journal of Innovation Management, March 2005, special issue in Honour of Keith Pavitt. See also most recently, Baldwin, R. (2016). The Great Convergence. Information Technology and the New Globalization, The Belknap Press of Harvard University, Cambridge, Mass.

${ }^{10}$ Romer, P. (1994). "New Goods and the Welfare Costs of Trade Restrictions". The Journal of Development Economics, 43(1):6. 
improve compliance with international patent rules and standards. With but a few exceptions, emerging and developing countries have been especially active in pursuing this new pathway to industrialization. ${ }^{11}$

However, the distribution of gains from trade and global networks remains highly unequal, both within countries and between them. According to the OECD, large sections of the middle classes in advanced countries have not experienced gains in their real incomes over the past 25 years or so. ${ }^{12}$ Branko Milanovic's pioneering study on "global inequality" shows that, between 1988 and 2008, two groups experienced the greatest real per capita income gains: (1) the global top richest $1 \%$ concentrated in the advanced countries; and (2) median income groups in emerging economies, predominantly China, but also India, Thailand, Vietnam, and Indonesia. The result is a major increase in global inequality, with erstwhile median income households in advanced economies being the main relative losers. ${ }^{13}$ Recent OECD research shows that wage inequality has increased in recent years and that globalization and digitalization are widening the gap between the growth of wages and productivity. Equally important, the polarization of labor demand threatens those with average skills. The perceived threat is that we are heading toward a "winners take all" economy.

Of great concern for the distribution of gains from trade for innovation is evidence that points to growing corporate concentration. Global oligopolies are spreading, especially in "industries characterized by network externalities (such as firms in the expanding digital sector) with 'winner-take-most' features, and the integration of different economies can help to allow a small number of dominant firms (like Apple, Facebook, Google in the US, and Baidu, Alibaba, Tencent in China) in each industry to emerge and earn growing rents. There is certainly a widespread perception that some multinational enterprises (MNEs) have become excessively large and powerful and, in some cases, use their

\footnotetext{
${ }^{11}$ Baldwin, R. (2016). "The World Trade Organization and the Future of Multilateralism". Journal of Economic Perspectives, 30(1): 95-116.

${ }^{12}$ OECD, 2017, Fixing Globalisation: Time to Make it Work for All, OECD, Paris, April: p. 9. ${ }^{13}$ Milanovic, B. (2016). Global Inequality. A New Approach for the Age of Globalization. Cambridge, MA: Harvard University Press.
} 
power to entrench their position (e.g., pharmaceutical companies pushing for stronger protection of intellectual property rights in developing economies). Tax evasion and aggressive tax avoidance by some MNEs, together with bribery and corruption, further add to the problem" (OECD, 2017: ibid.). ${ }^{14}$

All of this suggests that liberalization needs to be accompanied by well-resourced and targeted active government policies to facilitate structural adjustment, provide training and compensation to displaced workers, and support the most vulnerable. Such policies are necessary for both economic efficiency and equity-related reasons. The above OECD study, for instance, makes a strong case for "complementing advances in globalization by policies to ensure that the benefits of trade, investment and digitalization are more widely and more equally distributed and that all feel they contribute to the dynamic environment created by these forces. Key policy tools include social protection and labor market activation policies, measures to ensure healthy financial markets, and strategic investments in education, skills, health, innovation and physical infrastructure." (OECD, 2017: Key Messages).

Even before the rise of the new "Economic Nationalism", existing trade-adjustment-assistance programs were woefully under-funded and subject to other problems (e.g., bureaucracy) that prevented them from achieving the goals of compensation and facilitating re-integration of displaced workers. Rather than expanding public policies to mitigate trade-adjustment costs, a resurgent economic nationalism appears committed to scaling back such policies even further. Of course, if economic nationalism leads to trade wars, there will be fewer workers displaced by import competition. Still, workers in exports industries will be hit and economic growth could suffer severely. Such was the result of the economic nationalism manifested in the Smoot-Hawley tariff of 1930, which led to retaliation by foreign partners and an exacerbation of the Great

\footnotetext{
${ }^{14}$ For similar findings about unequal distribution of gains from trade, see Making Trade an Engine of Growtrh for All. The Case for Trade and for Policies to Facilitate Adjustment, a report prepared for discussion at the meeting of G20 Sherpas, March 23-24, 2017, Frankfurt, Germany, prepared by the staff of the International Monetary Fund, The World Bank, and the World Trade Organization.
} 
Depression. The US economy was far less exposed to foreign trade back then; the impact of a trade war could be greater this time around.

In short, economic policy is essential in ensuring that gains and losses from trade are shared by all. Equally important however is the role that economic policy plays in fostering a wide distribution of gains from trade for innovation. After all, a country can use, absorb, and further develop imported ideas and knowledge only if its firms (both producers and users) can tap into strong domestic technological and management capabilities.

This may be less of a concern for the United States and other advanced countries whose innovation systems have developed over more than a century. ${ }^{15}$ However, for countries like China or Malaysia, developing such capabilities as a latecomer requires supporting industry and innovation policies. ${ }^{16}$ This is why Romer's proposition needs to be balanced with the "infant economy" argument, as formalized by Greenwald and Stiglitz (2006).

Philippe Aghion (2014) summarizes the argument as follows: For developing countries with a nascent industrial sector, "full trade liberalization will make it very costly for domestic industrial sectors to invest in learning by doing ... since domestic costs are initially higher than foreign

\footnotetext{
${ }^{15}$ But even for the US, Ralph Gomory, a former IBM SVP for R\&D, has documented that "the self-interests of our corporations, especially our large global corporations, can diverge from the interests of our country, We need to find ways to fundamentally change the motivation of corporations to align with those of our country." (Gomory, Ralph, 2009, "Country and Company: Part I - Divergent Goals", The Huffington Post, March 16. Updated March 25, 2011, http://www.huffingtonpost.com/ralph-gomory/country-andcompany-part_b_174875.html). For a detailed analysis, see Berger, S. (2013). Making in America: From Innovation to Market, Cambridge, MA: MIT Press.

${ }^{16}$ See for instance, Ernst, D. (2017). Advanced Manufacturing and China's Future for Jobs, in Paus, Eva (editor), Emerging Dystopias? The New Technological Revolution and the Future of Work, Cornell University Press, Ithaca, NY 14850; Ernst, D., 2011, Indigenous Innovation and Globalization: The Challenge for China's Standardization Strategy, UC Institute on Global Conflict and Cooperation; La Jolla, CA and East-West Center, Honolulu, HI., 123 pages http://www.EastWestCenter.org/pubs/3904 ; and Ernst, D., 2004, "Global Production Networks in East Asia's Electronics Industry and Upgrading Perspectives in Malaysia," chapter 3 in Shahid Yusuf, M. Anjum Altaf and Kaoru Nabeshima (eds.), Global Production Networking and Technological Change in East Asia, The World Bank and Oxford University Press.
} 
costs [and] the social benefits from learning by doing are not fully internalized." ${ }^{\prime 7}$ At the same time, innovation theory tells us that strengthening national innovation capabilities improves a country's ability to engage in and benefit from the international trading system" (Kim and Nelson, 2000; Ernst et al., 1998). In fact, the gains from trade through global network integration are contingent — or a country's capacity to capture those gains depends - "on the structure of specialization and the level of development” (Kowalski et al., 2015).

\section{A resurgent economic nationalism creates new uncertainty}

Rising economic nationalism, as embodied in the "America First" doctrine of the Trump Administration, has added new challenges to this enlightened globalization agenda. In a fundamental break with established US trade diplomacy, the new US trade dogma is ostensibly predicated on the fundamental arguments of mercantilism that trade is essentially a zerosum game in terms of its welfare effects, and hence an optimal policy is to ensure that exports exceed imports. ${ }^{18}$

At his inauguration, President Trump laid out a vision of unabashed protectionism: "We must protect our borders from the ravages of other countries making our products, stealing our companies and destroying our jobs. Protection will lead to great prosperity and strength." Moreover, "We will follow two simple rules: buy American and hire American." Success is measured by the following criteria: any trade deal "must increase the

\footnotetext{
${ }^{17}$ Aghion (2014: 498) argues that "adequately targeted sectoral intervention, e.g., to more skill-intensive or to more competitive sectors, can enhance growth," especially for developing countries who seek to benefit from trade and global network integration.

${ }^{18}$ For Thomas Mun, a director of the East India Company and one the most well-known of the mercantilist writers, the best way to increase the wealth of a nation was to "sell more to strangers yearly than we consume of theirs in value." (Mun, Thomas, 1664, England's Treasure by Foreign Trade, republished in 2013 in Thomas Mun, The Complete Works: Economics and Trade, Newton Page, Jul 29, 2013 - Business \& Economics - 296 pages).
} 
growth rate [of the economy], decrease the trade deficit and strengthen the US manufacturing base". 19

While some observers had hoped that over time harsh rhetoric would yield to pragmatism, no such change was in evidence during the first months of the Trump Administration. By May 2017, “... [t] he administration has not distanced itself from the doctrine that bilateral trade balances are to be considered the litmus test to determine whether particular trade agreements are benefitting the United States. In addition, bilateral agreements are to be the path forward, not multi-party agreements. There is currently no positive trade agenda for the United States participating in, much less leading, multi-party agreements - nothing for the WTO, nothing for the Trade in Services Agreement (TiSA), nothing on replacing the Trans Pacific Partnership Agreement and nothing with respect to continuing negotiations with the European Union through the Trans-Atlantic Trade and Investment Partnership (TTIP).,"20

Such "protectionist bilateralism" creates pervasive uncertainty with unknown consequences for the rules-based system of global governance established after World War II. To many foreign observers, the "America First" doctrine is tantamount to a declaration of economic warfare. Specifically regarding China, a declared intention of the Trump administration, repeated frequently on the 2016 campaign trail, has been to impose an across-the-board $45 \%$ tariff on Chinese imports. In addition, the Trump administration is threatening to implement broad sanctions under Section 301 of the 1974 US Trade Act, restrictions on steel and aluminum imports due to "national security" considerations, and aggressive screening of inward Chinese FDI.

The United States remains the predominant economic and military power, but it is increasingly unable to dictate the rules of international trade.

\footnotetext{
${ }^{19}$ Wolf., Martin, 2017, “Trump and Xi battle over globalization", Financial Times, February 1.

${ }^{20}$ Wolff. Alan Wm., 2017, The U.S.-Japan Relationship and American Trade Policy, Observations of a Former Trade Negotiator, presented at the conference on Japan's Global and Domestic Futures and the U.S. Relationship, The Center on Japanese Economy and Business, Columbia Business School, Tokyo, Japan, May 25. The author is Deputy Director General of the World Trade Organization and a previous Chairman of the Board of the U.S. National Foreign Trade Council (NFTC).
} 
Both the United States and China would pay a heavy price in the case of a trade war, with severe knock-on effects in other areas as well. The Chinese government has already begun to issue warnings that a US-led trade war will hurt both sides. ${ }^{21}$

The Chinese government may have a strong desire to negotiate a Grand Bargain, "partly because it needs time to identify the bottom line of the Trump administration and partly because of the critical importance of the United States as its largest export market." 22 However, if no compromise can be worked out, China can very effectively retaliate and can do considerable damage to US exports (agriculture, Boeing, semiconductors). In particular, China could target companies in critical Midwestern swing states that enabled Donald Trump's victory. China is prepared for a long battle of attrition, ranging from a campaign of silence and noncooperation to retaliatory open-trade warfare if it came to that. In the open US system, it is much harder to manage discontent and political blow back than in the authoritarian Chinese system. A US-engineered trade war could easily backfire.

Equally important, a return to mercantilism plays havoc on the domestic policy front as well. Proposed changes in healthcare and for tax reform have the potential to be highly regressive, exacerbating the inequality problem in the United States. In 2014, the US income distribution (as measured by a Gini coefficient of more than 40 on a scale of 100) is now more like that of a developing country than an advanced country." 23 In addition, the White House has proposed drastic cuts in the budgets for programs on trade-adjustment-assistance, social welfare, climate change, as well as major science and technology programs. Taken together, these policies are likely to weaken even further the scope for structural adjustment policies needed to compensate the losers from trade, to provide

\footnotetext{
${ }^{21}$ For example, Wall Street Journal, "China Warns the US on Trade: We Are Both Hurt in a Fight, August 3, 2017, Available at: https://www.wsj.com/articles/china-pushes-back-onu-s-accusations-on-trade-urges-cooperation-1501751592.

${ }^{22}$ Zhai, Fan, 2017, "Trade Cooperation and Conflicts between the United States and China: Risks and Realities", chapter 16, in Posen A.S. and Ha Jiming, editors, US-China Cooperation in a Changing Global Economy, PIIE Briefing 17-1: 151.

${ }^{23}$ Wolf, Martin, 2017, “A clash of civilisations or community?", Financial Times, 12 July: p. 9.
} 
training for displaced workers, and to invest in new advanced manufacturing and service industries.

\section{Rethinking the framework for Megaregionalism 2.0}

Writing new rules and updating old ones is of the essence in order to accommodate unprecedented change. Equally important are transparent processes of negotiating and implementing new framework conditions.

\subsection{Limitations to multilateralism}

Developing such rules at the multilateral level would be best in theory, but the success in expanding the membership of the WTO to 164 economies with very different policy priorities has rendered progress difficult: the Doha Development Agenda (DDA), launched in November 2001, has been at an impasse since 2013 and is unlikely to move forward in the short-term (if at all). ${ }^{24}$ The last time that comprehensive new trade rules were put into place in the global system was in 1995, with the implementation of the Uruguay Round. The new international economy, in which globalization plays an essential role, has changed radically since then but without global rules to accommodate and facilitate it.

Hence, bilateral and regional trade agreements have emerged as key commercial policy initiatives designed to bring down barriers to trade and update trade-related rules, regulations, and standards. These agreements are mostly in the form of bilateral free-trade areas (FTAs), as they tend to be the easiest to negotiate as "coalitions of the willing" between like-minded economies. While subject to the (mild) exigencies of Article XXIV of the GATT/WTO, these FTAs can vary significantly in terms of depth, coverage, and ambition. Bilateral and regional FTAs negotiated by OECD economies tend to be the "deepest", but FTAs

\footnotetext{
${ }^{24}$ For the US, the decline of the Doha round was definitive, even before the Trump administration came to power. For former USTR Michael Froman, "moving beyond Doha... [and] freeing ourselves from the strictures of the Doha framework" was the main theme of his remarks to the 10th Ministerial Conference of the WTO in Nairobi, Kenya (USTR 2015b).
} 
among developing economies are also increasing in ambition, with the ASEAN Economic Community (AEC), established in December 2016, being a salient example.

To date, empirical estimates of the economic effects of existing FTAs tend to be positive (see WTO 2011 and Gilbert 2016 for surveys). Still, given the importance of global and regional production networks as sources of $21^{\text {st }}$ century trade and investment, FTAs with a limited number of partners will inevitably fall short of their potential for many reasons, from trade and investment diversion to costs associated with rules of origin. Moreover, few are large enough to boast the possibility of creating global industrial standards.

\subsection{A focus on new international benchmark standards for trade}

"Megaregional" trade agreements, such as the TPP and the Regional Economic Comprehensive Partnership (RCEP), are ambitious trade agreements devised to address these problems by including many partners at varying levels of economic development and embracing wide coverage and depth. The TPP in particular was intended to be a " $21^{\text {st }}$ century" trade agreement with the aim of setting a "gold standard" for regional cooperation. Signed by its 12 negotiating member states in February 2016, the TPP included cutting-edge chapters on the digital economy, state-owned enterprises engaged in trade, trade in services, intellectual property rights (IPR) protection, non-tariff barriers, and protection of labor and environmental standards, while at the same time cutting virtually all tariffs to zero (except in a few notable sectors, such as agriculture).

Megaregional trade agreements seek to bypass the stalemate in multilateral negotiations under the WTO. While its original intentions were ambitious when it was launched in November 2001, the DDA has yielded little in terms of concrete progress: the "Aid for Trade" initiative, the expansion of the Information Technology Agreement and the Government Procurement Agreement, and the Trade Facilitation Agreement are the main fruits of more than a decade and a half of negotiations. The main purpose of megaregionals, composed of a group of like-minded econo- 
mies, is to find ways to create and harmonize new international benchmark standards for trade, for instance for IPR, technical standardization, government procurement, taxation, and competition policy, in a way that is not possible in the context of the wider WTO membership, as well as to bring down traditional tariff and non-tariff barriers. The move toward megaregionalism is driven by this need for deep integration in order to foster knowledge-sharing within international corporate networks of production and innovation.

The new architecture of these megaregional trade agreements is shaped by the emergence of international corporate networks that integrate dispersed production, engineering, product development, and research across geographic borders. ${ }^{25}$ While the proliferation of global production networks dates back to the late 1970s, a more recent development is the rapid expansion of global innovation networks (GINs), driven by the relentless slicing and dicing of engineering, product development, and research. ${ }^{26}$

Megaregional trade agreements attempt to provide new international benchmark standards for international trade and investment within such complex global networks of production and innovation. And yet, we still know little about how the megaregionalism trend might change the link between trade and innovation.

\footnotetext{
${ }^{25}$ On the proliferation of these networks, see Ernst, D., 1997, From Partial to Systemic Globalization: International Production Networks in the Electronics Industry, Berkeley Roundtable on the International Economy (BRIE) Working Paper 98, April: 113 pages; Ernst, D. and P. Guerrieri, 1998, "International Production Networks and Changing Trade patterns in East Asia: The Case of the Electronics Industry", Oxford Development Studies, Vol. 26, No. 2; Ernst, D. and Linsu Kim, 2002, "Global Production Networks, Knowledge Diffusion and Local Capability Formation", Research Policy, special issue in honor of Richard Nelson and Sydney Winter; Ernst, D., "Complexity and Internationalization of Innovation: Why is Chip Design Moving to Asia?", International Journal of Innovation Management, March 2005, special issue in Honour of Keith Pavitt.

${ }^{26}$ Ernst, D. (2012). "Production and innovation networks, global", in Encyclopedia of Global Studies, Sage Publications (pp. 1393-1397). Thousand Oaks, CA; Ernst, D., A New Geography of Knowledge in the Electronics Industry? Asia's Role in Global Innovation Networks, Policy Studies \#54, August 2009, East-West Center, Honolulu, USA.
} 


\subsection{Potential economic effects}

Nevertheless, empirical economic analysis provides estimates of overall potential economic and structural effects. As noted in Chapter 1, the economic gains of these agreements are estimated to be large. For example, Petri and Plummer (2016) estimate that the TPP would increase global incomes by about a half-trillion dollars, with the United States being the biggest winner ( $\$ 131$ billion per year relative to the baseline beginning in 2030). The economic impact of RCEP could increase global incomes by even more; Petri et al. (2012) estimate the gains to be on the order of $1.9 \%$ of member-country GDP by 2025 (\$664 billion), again relative to the baseline scenario. ${ }^{27}$ Importantly, this income growth will always be led by trade; for example, exports of RCEP economies are projected to increase by $14 \%$ due to the agreement. Since many of the most important variables driving these gains can be traced to non-discriminatory measures (e.g., improvements in trade facilitation, investment- and service-related measures, digital economy), non-partner countries are only marginally affected and, in some cases, gain due to these megaregional accords. Indeed, regionalism of the $21^{\text {st }}$ century is very different to that of the $20^{\text {th }}$ century, which relied on the liberalization of traditional parameters - such as tariffs — that lead to trade diversion. The Trump Administration pulled the United States out of the agreement, but the remaining 11 countries continue to negotiate a TPP without the United States, ${ }^{28}$ with the hope that it may join in the future. Also, several other economies (to date, Indonesia, the Philippines, South Korea, Taiwan, and Thailand) have expressed interest in possibly joining the TPP.

There have been legitimate worries that trade has a deleterious effect on income distribution, a salient contemporary policy concern, megaregional accords included. By improving efficiency via structural change, trade increases economic welfare, but the "winners" and "losers" of this process are different agents. The same is true of often disruptive transformations imposed on manufacturing and services by automation, smart robots,

\footnotetext{
${ }^{27}$ For details, see www.asiapacifictrade.org .

${ }^{28}$ Given the size of the United States, the TPP in its present form could not move forward without the United States, according to Chapter 30. To move forward, at a minimum, the remaining 11 economies must revise that chapter. On TPP-11, see Preface.
} 
3D printing, artificial intelligence, and the Internet of Everything. Certainly, it is a major public policy challenge to compensate the losers by promulgating compensation (e.g., through a strong general safety net, targeted programs to help trade-displaced labor, wage-insurance policies) and spearheading measures to facilitate quick re-entry into the job market (e.g., via training programs, job-market information, and job-matching programs).

An even more fundamental challenge is raised by the renewed debate about what role a "guaranteed minimum income" could play in creating a level playing field for all participants in global trade, including the current losers. While this is not the place for a detailed discussion, it is worth noting that the idea has a long history and has been supported by a broad coalition of leading economists, including Paul Samuelson, James Tobin, and Kenneth Galbraith in the late 1960s. ${ }^{29}$ Today, the search for viable mechanisms of guaranteed minimum income has moved to center stage in debates about compensating the losers of job-displacing technical change. ${ }^{30}$ It is an approach that could play an important role for an enlightened globalization agenda and requires further study.

In short, a combination of these support policies is necessary to ensure equity and efficiency, as well as to reassure the public that trade is not the enemy of the working class, a theme embraced by populists of the left and the right. Globalization needs to be managed, not thwarted, which would be to the economy's severe detriment.

Still, the effects of trade on income distribution are less significant than is often conjectured in the media. In fact, trade liberalization can actually improve income distribution. For example, in the case of the TPP,

\footnotetext{
${ }^{29}$ See for instance "Economists' Statement on Guaranteed Annual Income, 1/15/19684/18/1969 folder, General Correspondence Series, Papers of John Kenneth Galbraith, John F. Kennedy Presidential Library. Cited in: Jyotsna Sreenivasan, "Poverty and the Government in America: A Historical Encyclopedia." (Santa Barbara: ABC-CLIO, 2009), page 269. It is noteworthy that the Nixon Administration responded with a policy initiative The Politics of a Guaranteed Income: The Nixon Administration and the Family Assistance Plan,1973, by Daniel Patrick Moynihan.

${ }^{30}$ See for instance, Ford, M., "Rise of the robots: technology and the future of work", in Paus, Eva (editor), Emerging Dystopias? The New Technological Revolution and the Future of Work, Cornell University Press, Ithaca, NY 14850.
} 
Petri and Plummer (2016b) estimate that, because labor gains more than capital and the lower prices of goods from TPP countries would disproportionately help the less prosperous in the United States, income distribution in the United States should improve. ${ }^{31}$ These estimates are consistent with those of Lawrence and Moran (2016).

How these megaregional trading agreements will affect innovation and invention will clearly determine, to no small degree, their ultimate success. Sustainable economic growth and prosperity for all increasingly depends on innovation and invention, and this is true for developed, emerging, and developing economies. For example, global innovation networks are evolving hand-in-hand with the global production networks in the Information and Communications Technology (ICT) industry; in turn, updated and improved rules and standards in the ICT industry, as well as lower barriers to trade, expand significantly the potential of these networks and the ability of emerging and developing economies to participate in them.

\section{The Two-way Nexus between Innovation and Trade}

\section{Innovation reshapes international trade and production}

Innovation has reshaped the structure of international trade and production, inter alia, through generic technology platforms such as information and communication technology, new materials, and biotechnology. ${ }^{32}$

\footnotetext{
${ }^{31} \mathrm{http} / / /$ voxeu.org/article/economics-tpp-winners-and-losers .

${ }^{32}$ According to recent MIT research, these generic technology platforms encompass, for instance: Synthesized new materials (e.g., nano-engineering), as well as custom-designed and recycled materials; continuous manufacturing of pharmaceuticals and biomanufacturing; green sustainable manufacturing; mass customization, for instance through Additive Manufacturing (3DP) and reconfigurable robotics which might enable Continuous Manufacturing in small batch sizes and break down the boundaries between fabrication and assembly; and integrated solutions through bundling of physical products with services and software. (Berger, S., 2013, Making in America. From Innovation to Market, Cambridge, MA: The MIT Press.)
} 
Richard Baldwin and colleagues have captured the transformation of trade through innovation. ${ }^{33}$ For Baldwin:

Trade in today's world is radically more complex. The information and communications technology revolution has internationalized supply chains, which has created a tight supply-side linkage between trade and FDI: the "trade-investment-service-IP nexus". Today's international commerce comprises complex, two-way flows of goods, services, people, ideas and investments in physical, human and knowledge capital - in addition to trade in raw materials and final goods. These connections make it almost irrelevant to talk about trade without also talking about FDI — at least for many products and markets....As a result,...trade and investment are neither complements nor substitutes - they are simply two facets of a single economic activity: international production sharing. ${ }^{34}$

The electronics industry has been in the vanguard of this transformation; production is increasingly characterized by fragmented trade at the regional level - i.e., a regional division of tasks across multiple countries in the production of a final good - and is being driven by technological innovation. ${ }^{35}$ But this modularization of all stages of the

\footnotetext{
${ }^{33}$ Baldwin, R., 2013, "Global supply chains: why they emerged, why they matter, and where they are going", chapter 1 in: D.K. Elms and P. Low, eds., 2013, Global value chains in a changing world, WTO, Geneva: pages 13-60; Baldwin, Richard and J. López González (2013) "Supply-Chain Trade: A Portrait of Global Patterns and several testable hypotheses” NBER Working Paper 18957 http://www.nber.org/papers/w18957.pdf.

${ }^{34}$ Baldwin, R. 2013, "The New Relevance of FDI: The GVC Perspective", in World Economic Forum, Foreign Direct Investment as a Key Driver for Trade, Growth and Prosperity. The Case for a Multilateral Agreement on Investment, Geneva: p. 13.

${ }^{35}$ Ernst, D., 2009, A New Geography of Knowledge in the Electronics Industry? Asia's Role in Global Innovation Networks, Policy Studies \#54, August 2009, East-West Center, Honolulu, USA. For empirical research on China's global network integration, see Watanabe, M., ed., 2014, The Disintegration of Production. Firm Strategy and Industrial Development in China, Edward Elgar, Cheltenham, UK, for the Insitute of Developing Economis (IDE), JETRO; and Ernst, D., 2014, From Catching Up to Forging Ahead?
} 
value chain has moved well beyond the electronics industry. Today, the dispersion of global networks of production, product development, and research is driving production and trade in myriad goods and services sectors.

\subsection{Trade as an enabler of innovation}

Equally important however is the other side of the trade nexus with innovation: the role of FDI as a channel of knowledge spillovers and co-invention, as articulated in Lee Branstetter's pioneering work. ${ }^{36}$ Economic research typically focuses on three specific channels through which trade could strengthen a region's innovation capacity: (1) imports, FDI, and technology licensing; (2) learning-by-exporting, which both exposes the region to foreign technology and intangible knowledge as a source of product and process innovation; and (3) competition, which may reduce monopoly rents from innovation and create pressure to increase productivity. ${ }^{37}$

Thus, the link between trade and innovation is critical for trade laws and diplomacy as well as for innovation policy. Equally important is that trade and innovation are mutually interdependent: innovation has increased the benefits of trade due to its salutary effects on costs and the generation of a greater variety of inputs to firms and goods to consumers. At the same time, international trade facilitates the application of new innovations by providing new markets and economies of scale.

China's Prospects in Semiconductors, East-West Center Working Papers: Innovation and Economic Growth Series, no. 1 (November 2014).

${ }^{36}$ Branstetter, L., 2006, "Is Foreign Direct Investment a Channel of Knowledge Spillovers: Evidence from Japan's FDI in the United States," Journal of International Economics, vol. 68, February 2006, pp. 325-344. See also Branstetter, L., Guangwwei Li and Francisco Veloso, 2014, "The Rise of International Co-invention", Chapter in forthcoming NBER book The Changing Frontier: Rethinking Science and Innovation Policy, Adam Jaffe and Benjamin Jones, editors.

${ }^{37}$ Kiriyama, N., 2012, Trade and Innovation: Synthesis Report, OECD Trade Policy Papers, No.135, OECD, Paris, and Onodera, O., 2008, Trade and Innovation: a Synthesis Paper, OECD Trade Policy Working Paper No.72, August 7. 


\section{Alternative futures for Megaregionalism 2.0}

\subsection{Impacts of the US withdrawal from the TPP}

To assess the stakes involved in the TPP, which was the first megaregional agreement to be concluded in the Asia-Pacific region, let us begin with some general economic context. Of the world's \$19 trillion in trade in 2013, \$12 trillion involve countries of the Asia-Pacific Economic Cooperation (APEC) organization ${ }^{38}$ as either an exporter or importer or both (World Bank, WITS). Its share of FDI flows are no less impressive; in 2014, APEC accounted for 53\% of global FDI inflows (UNCTAD 2015).

These figures reflect in part the explosive growth of the Chinese economy; China is now the world's largest trader, with a total trade of $\$ 3$ trillion in 2013 up from \$280 billion in 1995 (World Bank, WITS). It was the largest recipient of FDI flows in 2014 and the third largest source of FDI flows, behind the United States and Hong Kong (UNCTAD 2015). It is also the first or second most important export market of nearly all other Asia-Pacific economies, and its share in their exports has been rising in all cases since 1995 (World Bank, WITS).

Indeed, the structural transformation of the Asia-Pacific economy has been dramatic as well. The region is the testbed of the new global value chains made possible by the spread of ICT and improvements in connectivity. Asia has become a global manufacturing hub; it collects components from many countries and bundles them into products destined for European, US, and other markets. China is now a key hub in this process, but many other countries have emerged as important upstream participants as well, including advanced industrial countries. The latter play especially important roles in organizing value chains, linking stages from early design through manufacturing, and ultimately marketing.

\footnotetext{
${ }^{38}$ The membership of the Asia-Pacific Economic Cooperation (APEC) forum currently includes 21 economies: Australia, Brunei Darussalam, Canada, China, Chinese Taipei, Chile, Hong Kong, Indonesia, Japan, Malaysia, Mexico, New Zealand, Papua New Guinea, Peru, the Philippines, Russia, Singapore, South Korea, Thailand, the United States, and Vietnam.
} 
Radical changes in technology are also creating new markets and forms of economic integration. The most prominent example is the rise of the digital economy, made possible by the internet and related innovations. ICTs reduce costs by automating business processes, improving information flows that enable producers to organize more complex production systems, and making many kinds of services, and especially new services emanating from the digital economy, tradeable (APEC, 2008). ICT is ubiquitous; internet services are regularly accessed in developed and developing economies. The digital revolution is fundamentally altering the way governments interact with their citizens as well as with each other (Tapscott and Agnew, 2015).

As noted above, rules for the digital economy have not kept pace with these massive changes; indeed, they are still in their infancy. The Uruguay Round was concluded well before the digital economy took shape. The more recent WTO-based Information Technology Agreement (ITA) and now the ITA2 are pertinent to the digital economy but relate to trade in physical goods, not electronic goods and services, and do not address rulemaking issues (see Chapter 17).

Economic development is also making the service sector increasingly prominent. The share of services value-added in GDP has risen virtually in every country in recent years and is now greater than $50 \%$ in most developed and emerging markets; in the TPP economies, for example, the range is between $70 \%$ and $78 \%$ for the high-income economies, and $50 \%$ to $63 \%$ for all others, with the exceptions of Brunei Darussalam (31\%) and Vietnam $(43 \%) .{ }^{39}$

Negotiations on the TPP began in 2008, building on the earlier TransPacific Strategic and Economic Partnership agreement concluded by Brunei, Chile, New Zealand, and Singapore. When signed, the TPP included 12 APEC members representing about two-fifths of world output and one-quarter of global trade, ranging widely in income from Vietnam and Peru to Japan and the United States. The 2011 TPP Leaders Statement underscored five objectives: comprehensive market access; a regional agreement that facilitates production and supply chains; cross-cutting trade issues; challenges emerging from new technologies; and a "living

\footnotetext{
${ }^{39}$ World Bank, http://data.worldbank.org/indicator/NV.SRV.TETC.ZS.
} 
agreement" that brings in additional members over time (Congressional Research Service 2015). After a long and intense negotiating process, the accord itself accomplished these goals; in October 2015, an agreement was reached and a final version was signed by all 12 economies in February 2016. Many countries ratified the agreement over the following year. But the Trump Administration decided to notify its 11 partner countries of its intention to withdraw from the agreement on Monday, January 23, 2017, three days after officially taking office.

The TPP negotiations do not include China, the second largest economy in the Asia-Pacific. Chinese membership could have advanced the agreement's integration objectives given its size and role as a trading hub in East Asia, and would have made the agreement a more compelling model for future agreements. Including China might have made it more difficult to agree on rules, and, to some observers, it was better to start this unusually challenging negotiation with a less complex mix of partners. Estimates that compare the benefits of the TPP with those of larger alternatives that include China confirm the importance China's participation (Petri et al., 2012).

The TPP seeks to improve market access by eliminating "highhanging" barriers that escaped prior rounds of liberalization in the WTO. Even so, negotiators could not agree on a region-wide approach, and so left it up to each member whether to keep old FTAs in place or rewrite them, and whether to make new offers on a bilateral or multilateral basis (Barfeld 2011). Thus, new liberalization focused on links not previously covered by FTAs, such as Japan-US trade, as well as sectors neglected in existing FTAs, such as agriculture, technology, and services. It also included provisions to help align technical and sanitary and phytosanitary (SPS) standards.

The TPP attempted to circumscribe national regulations in several areas in order to promote deeper integration. For example, it liberalizes all services and trade-related investments except for sectors reserved on a negative list; attempts to keep digital trade free of barriers that apply to physical goods; prescribes national treatment in government procurement; prohibits government support for state-owned enterprises as they compete abroad; offers foreign investors national treatment both pre- and postinvestment; and allows foreign investors to challenge government decisions 
that reduce the value of their assets through an arbitration process ("investor-state dispute settlement", or ISDS). In several of these policy areas, regulations to protect health and safety are explicitly reserved for national governments, including especially the regulation of the consumption of tobacco.

\subsection{TPP withdrawal by the Trump administration and its implications}

During the 2016 US presidential campaign, all major candidates opposed the TPP agreement. This included Hilary Clinton, who was a strong supporter of the agreement while US Secretary of State. Trade is an easy target for criticism in any US election - as well as elsewhere — but the strong negativity of this election cycle was in many ways unprecedented. Democratic contender Bernie Sanders and Republican candidate Donald Trump were the most emphatic in targeting trade as a multinational corporate grab and "threat to democracy" (Sanders) or "another disaster done and pushed by special interests" (Trump). While presenting no convincing evidence to support these arguments, the candidates used antagonistic rhetoric toward trade in general and the TPP in particular as means to extoll their populist credentials. Globalization has become a political punching bag as never before in the United States, at least in the post-war era.

Rhetoric aside, the TPP was actually a good deal for the United States. After all, the United States was clearly the lead party in the TPP negotiations and pushed relentlessly its own interests and comparative advantage industries, e.g., taking strong positions on the inclusion of services, tariff reductions in high-end manufactures, ISDS, disciplines on state-owned enterprises, IPR, and labor standards, often facing significant resistance from its partner-countries (one reason why it took over six years to negotiate). It should come as no surprise that economic studies would suggest that the United States would gain the most. Indeed, parties criticizing the TPP in the other 11 member-economies often opposed it because, in their view, it was an agreement that favored US interests disproportionately. 
In addition to foregone losses in terms of economic welfare, pulling out of the TPP is costly to the United States for a number of additional reasons:

- Since Asia-Pacific economies are interested in opening up markets with or without the United States, with the rejection of the TPP, additional bilateral, sub-regional, and even regional FTAs will be formed, with the United States suffering the associated trade and investment diversion;

- In particular, this pertains to RCEP (discussed below). Not only will the United States likely suffer from trade and investment diversion in certain sectors but it would also find itself outside of discussions that may well serve to create templates for new rules governing trade, given the vacuum left by the TPP;

- The United States has extensive strategic interests in the Asia-Pacific region, which was true long before President Obama's "Asian Pivot". With its withdrawal from the TPP, the region will continue to question the commitment of the United States as a strategic partner (this is a point frequently made in the related literature, including the USITC February 2016 Report);

- The US commitment to being a leader in forging new, effective global governance of the international marketplace in the $21^{\text {st }}$ century is also now being questioned, not just due to its withdrawal from the TPP but also the new Administration's insistence on renegotiating NAFTA, possibly renegotiating or even abrogating the US-South Korea FTA, and threats to withdraw from the WTO;

- The Labor Chapter of the TPP and associated bilateral side letters with Vietnam, Malaysia, and Brunei are remarkable in that they ensure that there will be no race to the bottom in terms of labor regulations and guarantee freedom of association, the right to strike, prohibition against child labor, and other measures consistent with the ILO Declaration. This is not the first time that the US has included a labor chapter in an FTA, but it is the first time that it is actionable.

Perhaps the greatest irony is that the biggest beneficiary from the US withdrawal from the TPP will likely be China, despite the fact that during 
the US 2016 Presidential campaign Donald Trump was particularly critical of China and the role that it is playing in the global system. Strangely, one of his arguments against TPP was that it would help China, even though China was not a negotiating partner and, in fact, was slated to lose the most due to trade and investment diversion and preference erosion (Petri and Plummer, 2016). In addition to not having to bear the negative effects of US participation in the TPP, the loss of stature of the United States in the region is clearly a big win for China. In fact, in terms of leadership, China now holds the upper hand in Asia, and certainly not just due to the US exit from the TPP. China has been active in providing technical assistant to many of the region's economies; its One Belt, One Road (OBOR) initiative is slated to increase Chinese economic integration with Asia and Europe significantly; and its Silk Fund is being devoted to helping spur economic development along the OBOR.

The US exit from the TPP will also increase incentives to finish the RCEP agreement by the end of 2017, a goal that has been set by China and other regional economies. The combined GDP of RCEP economies came to about $\$ 24$ trillion in 2016, somewhat larger than the TPP12. ${ }^{40}$ RCEP is the culmination of long-standing efforts to pursue Asia-centered integration, mostly based on ASEAN's efforts to promote regional economic integration (Petri and Plummer, 2014). ASEAN's “Guiding Principles and Objectives for Negotiating the Regional Comprehensive Economic Partnership" define the goal of RCEP as "a modern, comprehensive, high-quality and mutually beneficial economic partnership agreement... [to] cover trade in goods, trade in services, investment, economic and technical cooperation, intellectual property, competition, dispute settlement" (ASEAN 2012). The Principles stress the need for flexibility, and the agreement will likely include special and differential treatment for developing members.

Thus far, there have been 18 RCEP rounds, with the last one having taken place in Manila in May 2017. Discussions have focused hitherto on trade in goods, trade in services, investment, economic and technical cooperation, intellectual property, competition policy, and legal and

\footnotetext{
${ }^{40}$ http://dfat.gov.au/trade/agreements/rcep/pages/regional-comprehensive-economicpartnership.aspx.
} 
institutional issues, including dispute settlement. E-commerce has also been part of the deliberations. Modalities for negotiations in various areas are still being ironed out. While sessions have been closed-door, information that can be gleaned from the websites of various RCEP participating governments suggests that some progress is being made on trade in goods and services and intellectual property, but much remains to be done by the end of 2017 .

The exact results of RCEP cannot easily be predicted at this time. On one hand, most negotiating members are outward-oriented and have incentives to produce a solid, comprehensive agreement, and official statements support this goal. Still, a history of shallow agreements by key member economies (such as ASEAN's and India's bilateral agreements), the focus on flexibility, the hesitancy to include behind-the-border measures, and the inclusion of economies that have been skeptical of deep economic integration in the past does not bode well for an ambitious outcome. Instead, the results may well include a relatively comprehensive deal on market access in goods; a limited positive-list approach in services; a strong agreement on investment, albeit with numerous carve-outs; few improvements in intellectual property rules; and provisions on economic and technical cooperation as well as special and differential treatment for low-income economies. The agreement will likely avoid strong commitments on behind-the-border issues.

But in any event, a successfully completed RCEP agreement will certainly enhance the leadership credentials of China at the same time that US credibility is fading in light of its exit from the TPP. Indeed, these trends are not only in evidence at the regional level but also globally: at the 2017 Davos meetings, President Xi of China gave a strong pitch in favor of globalization, while the newly assembled Trump administration was emphasizing "America First" and an inward-looking agenda. Some scholars are even concerned that the current administration could be undoing the post-war liberal order put in place by the United States. $^{41}$

\footnotetext{
${ }^{41}$ See, for example, Friedman, U. (2016). "How Donald Trump Could Change the World," The Atlantic, November 7. Available at: https://www.theatlantic.com/international/ archive/2016/11/trump-election-foreign-policy/505934/ .
} 


\subsection{Post-TPP Scenarios}

It is fair to say that the US withdrawal from the TPP took the region by surprise. The United States had led the negotiations with great enthusiasm and had negotiated hard to promote its comparative advantage industries, not only in services but also in high-tech manufactures and certain agricultural sectors and markets that had hitherto been closed to US exports. It included chapters on rules that the United States deemed were necessary for the $21^{\text {st }}$ century, e.g., with respect to IPR and the digital economy, and in creating a level playing field for the global economy, e.g., with respect to state-owned enterprises and foreign investment. The TPP also included a rigorous chapter on labor protection that was actionable to ensure that there would be no "race-to-the-bottom" in terms of labor rights and also a forward-looking environmental chapter. As noted above, in the national politics of many TPP partner-countries, the agreement was criticized for being too unbalanced in favor of US interests.

In addition to being unanticipated, the US withdrawal from the TPP was greeted with great trepidation in the region, particularly in its being a first concrete manifestation of the so-called "America First" dogma and the new inward-looking protectionist bilateralism of the Trump Administration. Asia-Pacific economic cooperation, led by the United States, had been growing in importance and ambition since the creation of APEC in 1989. This cooperation had been growing pari passu with Asian economic cooperation, from ASEAN to the "noodle bowl" of bilateral arrangements. It is interesting to recall that the United States in the past was worried that East Asian cooperation might lead to "a line drawn down the middle of the Pacific," as the Secretary of State under George H.W. Bush, James Baker, once famously quipped, but the line apparently is now being penned by the United States itself. In any event, Asian economic integration will likely proceed apace. In fact, the US withdrawal from the region increases the incentives for key countries to push forward on Asian integration.

This will likely first be in the form of the RCEP, as discussed above. The failure of the 12-country TPP to move forward gives a strong incentive to TPP negotiating members to finalize this other Asian megaregional, for not only the inherent economic benefits but also to keep the momentum 
toward concerted economic liberalization going (for the reasons discussed above). It also increases the potential gains to major RCEP members that were not party to the TPP, especially China. After all, it was always clear that the TPP would be more ambitious than RCEP; now, RCEP is the only game in town.

But that may not be exactly true. The remaining 11 TPP memberstates are now considering going forward with the agreement, with the exception of the necessary revision in Chapter 30 to allow for the exclusion of the United States. ${ }^{42}$ The Abe Administration in Japan was at first skeptical about the TPP without the United States but has now decided to join in negotiations for a new TPP, with the hope that United States might join at a later date. On April 25, 2017, Prime Minister Abe appointed a Deputy Foreign Minister to be its chief negotiator for the new TPP without the United States. ${ }^{43}$ The reasons for the change of heart no doubt derive from an interest in keeping the Asian integration process going and cementing strategic relationships, goals prominent in the aspirations of other TPP members as well.

With Japanese leadership, the likelihood of the TPP11 scenario is high. It would be an attractive option for economies in the region, particularly given that the TPP is such an advanced agreement that could also serve as a template for domestic economic reform and a model for future negotiations, including for other megaregionals such as the Free-trade Area of the Asia-Pacific. It might also continue to push the RCEP to be a more comprehensive agreement, something that Japan and other TPP economies would like to see. Moreover, should TPP11 continue to move forward, it is likely that other countries who have expressed interest in joining the original TPP would consider joining.

The Trump Administration has expressed interest in bilateral, rather than regional, agreements. The potential benefits of bilaterals are limited for a number of reasons, including the fact that tariffs on US trade with

\footnotetext{
${ }^{42}$ Chapter 30 required, among other things, that at least 6 TPP members constituting at least $85 \%$ of aggregate TPP GDP would be necessary in order for the TPP to enter into force. Given the size of the US economy, its inclusion (as well as Japan's) is necessary. ${ }^{43}$ http://www.japantimes.co.jp/news/2017/04/25/business/deputy-foreign-ministernamed-japans-chief-tpp-negotiator/\#.WQBtuIjyiUk .
} 
Asia-Pacific partners are already relatively low, the benefits of bilateral FTAs in spurring regional production networks — an important motivation for Asia-Pacific economic integration — are limited due to the "Asian noddle bowl" problem, and a main motivation for megaregional arrangements in Asia is to avoid the inefficiencies associated with a bilateral approach. Nevertheless, the possibility of a bilateral FTA with Japan — by far the largest economy in the TPP after the US itself — has been tabled.

In short, Asia-Pacific economic integration will proceed with or without the United States. All countries would have been better off if the United States had moved forward with the TPP and continued to engage in concerted economic liberalization in the region, but the backlash against globalization and a populist agenda has put the US policy on a new course not seen since the 1930s. The editors of this book hope and expect this to be a temporary setback. Ironically, the US temporary withdrawal may create new opportunities for a more diversified megaregionalism 2.0 .

\section{Megaregionalism 2.0 building blocks - The book's message}

The main message of this book is that megaregionalism has the potential to improve the welfare of the region's citizens and that of the world as a whole. These benefits derive in part from the traditional economic effects of trade and investment liberalization via lower tariff and non-tariff barriers. But in the context of the globalized $21^{\text {st }}$ century economy, non-traditional aspects of integration are increasingly important in improving efficiency, productivity, and competitiveness, and "trade and innovation" links are a critical component of this process. Moreover, as with technological change and automation, structural change via trade implies that some economic agents will gain but others will lose. Hence, the key policy challenge facing governments is not merely how to write new rules for the modern economy and bring down barriers to economic integration but also to keep the pain of transition as mild and as rapid as possible and ensure that the most vulnerable in particular need to be protected. This includes well-funded policies in support of education and training, in order to foster local capabilities for management and innovation. 
Globalization needs to be managed via enlightened economic and social policies rather than impeded. This book takes a fresh look at these issues, by bringing together chapters from trade economists, policymakers, and trade negotiators, as well as from experts on innovation, intellectual property rights, competition law, technical standards, labor standards, and industrial development.

The book has five parts. Below, we offer a very brief summary of the salient issues addressed in the chapters forming each part. To begin, Part 1 focuses on economic analysis. In "The TPP: Potential Gains and Impediments" (Plummer), the economics of megaregionalism in general and the TPP in particular are evaluated in order to give context to other trade-and-innovation-related chapters of this volume. Using estimates from Petri and Plummer (2016), it shows that the TPP should generate large economic benefits throughout the region and could increase incentives to complete on-going megaregional accords, such as the RCEP. These results are echoed in, "The TPP: Promoting Waves of Innovation", by Lippoldt, who presents optimistic scenarios under which TPP might have boosted incentives for innovation, drawing on a unique data set.

Part 2 considers trade and innovation within global networks. In "Beyond Value Capture: Exploring Innovation Gains from Global Networks", Ernst explores how increasingly complex and diverse global corporate networks of production and innovation create new, yet little understood, challenges for national policies that seek to foster economic growth and prosperity through productivity-enhancing innovation. As countries differ in their capabilities to learn and innovate, they differ in their capacity to capture potential gains from integration into global networks. This analysis is followed by a Taiwanese case study on supply chain positioning and innovation by Chen Tain-Jy, which shows how a firm's position in global supply chains affects its ability and scope for innovation. The chapter reviews and evaluates the multiple innovation traps that Taiwanese firms face as a result of their deep integration into mostly modular global networks. Next, Hill focuses on trade and investment barriers in a key sector for innovation, i.e., solar and wind global value chains, and examines where value-added is located in related global production networks and what impact megaregionalism might have on 
trade and investment barriers. A chapter on trade secrets had to be withdrawn from the volume prior to publication.

Topics related to intellectual property, strategic patenting, and trade are addressed in Part 3. In "Patents and Technology Transfer through Trade and the Role of Regional Trade Agreements", Maskus explores what positive policy steps designers of regional trade agreements could take to enhance flows of technology stemming from an agreement, such as changes in patent rules and increasing flows of skilled labor. Feldman emphasizes that efforts to develop regional and global intellectual property frameworks need to focus on streamlining complexity and on the creation of new products, rather than the creation of new intellectual property games and stripped markets. "Harmony and Disharmony in Intellectual Property Law" (Chien) notes that the gap between the agreed-upon provisions within trade agreements on the one hand and the on-the-ground implementation on the other is large, due to how they are formed as well as due to problems associated with the absence of domestic policymakers at the table in responding to dynamic and evolving needs in implementation. Kahin provides powerful evidence that the digital economy has added new strategic dimensions to the use of patents. While megaregional trade agreements like the TPP may have little direct impact, they add new uncertainties related to the expanding use of ISDS by large multinationals. Corrective policies are needed to reduce the disadvantages for smaller, domestic-scale competitors.

Part 4 considers the critical role of technical standards in trade and innovation. Tassey looks at the impacts of technical standards on global trade and economic efficiency, developing a public-private asset growth model where investment decisions are based on variables that reflect (1) the complex systems nature of modern technology, and (2) the required public and private sector roles for providing the supporting technical infrastructure. Ramel and Blind examine the concentration of control over Standard Essential Patents and their economic impacts on the distribution of gains from trade for innovation. In "Patents, Standards and Borders," Contreras argues that SMEs and firms from less-developed countries are systematically disadvantaged in global standard-setting organizations (SSOs) due to a lack of a large patent portfolio and experience within SSOs. Karachalios and McCabe underscore that standards 
now operate in an increasingly complex environment which forces us to rethink the role of standards in global trade agreements. The chapter discusses how megaregional trade agreements could be used to promote globally open, inclusive, collaborative, and consensus-based standardization processes that would enhance cross-border trade and innovation. Wang Ping and Zheng Liang focus on China's standardization system and present a reform agenda to strengthen decentralized standard development in line with China's deep integration into international trade and global networks of production and innovation.

Finally, Part 5 offers new perspectives on trade and innovation policy. Carlos Braga considers whether a multinational-led model of development i.e., outward orientation with strong protection of IPRs - will become the norm for developing countries in the coming years, and what needs to be done to enable megaregional trade agreements to enhance innovation capabilities in developing countries. In "The Information Technology Agreement, Manufacturing and Innovation - China's and India's Contrasting Experiences", Ernst examines how a country's manufacturing and innovation capacity in a particular industry affects its approach to and its position in megaregional trade agreements, comparing the experiences of China and India. Helper and Kruger explore how to promote win-win outcomes in the development of global supply chains, comparing three alternative scenarios of the impact of global supply chains and trade agreements on innovation, wages, and sustainability. Lastly, Brown looks at the labor implications of the TPP and argues that, while not generally supported by organized labor, it is a progressive "game changer", particularly in light of the three TPP-side agreements negotiated with Vietnam, Malaysia, and Brunei that should dramatically elevate domestic labor rights. 